\title{
Introduction: New Media and Conflict in the Middle East
}

Isabel Bramsen, Simone Molin Friis, and Alexei Tsinovoi

The theme of this special issue is new media and conflict in the Middle East. During the recent decade, we have witnessed rapid changes in the global media and information environment. With the emergence of global networks of communication and the proliferation of communication technologies across the globe, the flow of information today is at an unprecedented magnitude, speed, and intensity. In the Middle East - a region, in which regimes' and elites' control of traditional print and audio-visual media has previously been close to complete (Weeden 1999; Lynch 2016) - these transformations have had profound social and political consequences. This special issue explores the various ways in which new media has become an inherent part of everyday life of millions of citizens, but also a crucial actor, tool, and arena in the conflicts of the region.

The media and communication revolutions of the $21^{\text {st }}$ century have introduced new empirical, theoretical, and methodological puzzles for scholars focusing on conflicts in the Middle East, particularly as to whether the new virtual public sphere, established by new media, can provide a platform for democratization and resistance. With the advent of the Arab Spring, many believed in the inherently emancipatory nature of these technologies. Their hope was that new media would bring about a new and more democratic Middle East, and that information and communication technologies could become valuable tools in the hands of people committed to democratization (e.g. Shirky 2011). Indeed, in many ways, new media enables a larger, more diverse group of actors to participate in the communicative struggle, along with governments and traditional communication elites. In societies with strict regime-controlled media, new media platforms thus provides an opportunity for transcending one-way communication by empowering marginalized and otherwise silenced groups to develop counter-discourses to the hegemonic 
narrative. Because new media facilitates forms of collective action that are cheaper, faster, and more accessible, they have often been regarded as tools of civil dissent and non-violent resistance, allowing citizens of the Middle East to challenge autocratic regimes. In relation hereto, these technologies have the potential to render local dynamics visible to international publics. Today, contemporary activists only need a mobile phone with a satellite connection to upload messages, images, and videos beyond the reach of the regimes and beyond the borders of their countries. This global interconnectivity enables activists to be in direct contact with foreign publics, and thus empower geographically dispersed groups to connect across physical divides.

However, new media and the global networks of communication are not only about emancipatory endeavours such as democratization, documentation of war crimes, giving voice to the marginalized, and non-violent forms of resistance. The media and communication revolutions of the $21^{\text {st }}$ century have also lead to a surge of repressive and violent activities, such as cyber warfare, terrorist recruitment, hate speech, and violent propaganda. Evidence of authoritarian regimes attempting to mobilize the new technological affordances to crack down on opposition has swiftly illustrated the empirical complexity of the new media environment. Moreover, militant groups and terrorist organizations are becoming remarkably adept at manipulating their impact and establishing their presences through the global networks of communication. Particularly, the Islamic State has successfully managed to exploit the transformation of the communication and information environment to capture international attention and creep into the collective consciousness of multiple publics across linguistic, national, and cultural borders. While militant groups previously relied on being noticed by larger media corporations, new media are allowing groups like the Islamic State to bypass old media and communicate their actions to global publics through more direct forms of communication. Thus, the same communication technologies that are enabling civil activists and marginalized groups to connect across borders and strengthen their collective voice are likewise allowing militant groups and terrorist organizations to advance their cause and reach new audiences across the globe.

In response to the accelerating flow of activist, rebel, and militant communication, governments and institutions are reacting by introducing new policies and initiatives aimed at countering the flow of communication. Rapidly, new forms of censorship and 
regulation are being introduced both by the regional regimes, who are desperately trying to regain control over the information environment, but also by the international powers, who are intervening in the region. As an example, the fifth pillar of Operation Inherent Resolve $(\mathrm{OIR})^{1}$ is aimed at 'exposing the Islamic State's true nature', partly through countering and delegitimizing the group's messaging online and preventing what is popularly termed "radicalization through the Internet" (U.S. Department of State 2016; U.S. Department of State 2014). Moreover, many social media corporations have increased the use of content moderation on their platforms - something, which fundamentally challenges the idea of an open, pluralist, virtual public sphere. In short, the online world has become a crucial battlefield of the rapidly evolving conflicts in the Middle East. However, the emergence of new media and the proliferation of communication technologies in conflict zones also present social science research with a number of new, more fundamental theoretical and methodological puzzles.

First, new media present new methodological opportunities and challenges. On the one hand, today's social media platforms, where millions of citizens offer their thoughts on a daily basis, present an unprecedented window into the internal debates taking place in conflict-ridden areas of the Middle East (Lynch 2016). Online communication thus offers researchers unique sources of insights and data, breaking the long-cultivated monopoly over information claimed by the regional authoritarian regimes. For example, videos recorded on smart phones and uploaded online provide unprecedented material for analysis of violent conflicts and atrocities. Nonetheless, accessing and analysing this data is not straightforward, as it is generated by messy networks of heterogeneous devices, which are in a state of permanent flux, contingent upon the policies of the private new media corporations. As the purpose of these public social platforms is not academic research, but private capital accumulation, innovative and often open-source approaches have to be further developed, to enable a better access for social scientists to the data generated by new media technologies.

Second, the proliferation of new media introduces conflict dynamics, which challenges key social science concepts. In many ways, modern-day combatants and activists are operating literally in a theatre of war, conducting operations as though they were on a stage, in an amphitheatre or Roman arena, acting out a drama in front of a global, yet

\footnotetext{
${ }^{1}$ The operation of the international against the Islamic State.

${ }^{2}$ Formerly known as Jabhat al-Nusra.

${ }^{3}$ The author wishes to thank Friedrich Kratochwil, Laura Roselle, Rasmus Gahrn-Andersen, the two
} 
partial and selective audience (Smith 2005). As smartphones and cameras become tools almost as invaluable as weapons for combatants and activists, the traditional boundaries between active combatants and civilian observers, as well as between kinetic tools of destruction and virtual tools of perception are becoming increasingly blurred. Moreover, as images, videos, messages, and stories from conflict areas circulate across national, cultural, and interpretative borders, local conflicts not only become increasingly global in nature, but also exceed the normal confines of time, place, and meaning. Increasingly represented, observed, and executed through force fields of communication and information, contemporary conflicts often defy fixed definition and take on a multispectral, densely entangled, phase-shifting character (Der Derian 2013). The kind of reiterative and emergent violence associated with these multifaceted confrontations does not always lend itself to the assumptions of rational action, methods of linear regression, nor to hopes for a progressivist future, which drive much of contemporary social science research. Thus, new ways of theorizing, conceptualizing, and analysing the nature and dynamics of conflicts and violent confrontations in the digital age are needed. We hope that this special issue will contribute to these endeavours.

In the first article, Chiara de Franco argues that in order to better understand the role of new media in the Middle Eastern context, we need to create a conversation between the practice approach in IR, and the medium theory in media studies. Scholarly attention thus should not only focus on the content of the media, but also include its role as an environment in which international practices emerge. In turn, this enables analysing the shifting boundaries between the public and the private practices, and the emergence of new public spaces for politics. This argument is then illustrated by following a Facebook campaign, in which Israeli and Iranian citizens attempt at the creation of a transnational advocacy network, where individuals are brought together by the very act of sharing their private experience of the conflict. de Franco argues that the case thus illustrates how the study of everyday practices lends itself to the study of media ecologies, thus refocusing attention from the significance of media content, to media environment, and the new public spaces it creates for politics.

Second, Joshka Ivanka Wessels discusses how and whether YouTube videos from the Syrian revolution can be used as legal evidence in a post-war process of transitional justice. Wessels shows how many Syrian video-activists invested great courage in doc- 
umenting war crimes to "provide evidence" and "tell the world" with the hope of changing the current situation or potentially use the videos as evidence in transitional justice. The YouTube clips from Syria are divided into 8 categories and assessed individually in terms of verifiability and probability for legal evidence. While the article acknowledges the revolutionizing amount of video documentation it is argued that videos from the Syrian revolution often lack contextual information such as date, time, geographical location as well as identity of the perpetrator and victim necessary for establishing evidence for transitional justice and war-crimes prosecution. A fraction of the YouTube videos may however be used to document war crimes especially if these are supported by other evidence.

In the third article, Jakob Skovgaard-Petersen addresses the media revolution's implications for religious communication by examining the use of new media by Sunni religious authorities in Syria. Skovgaard-Petersen begins by tracing the dramatic expansion and transformation of media in Syria, from near to complete state control over the intrusion of pan-Arab satellite television to the emergence of oppositional outlets and rebel media. Following this overview, Skovgaard-Petersen turns to the question of how the media revolution has manifested itself in the field of Sunni Islam. By tracing the use of new media by Sunni religious actors, Skovgaard-Petersen identifies both the introduction of new genres of religious communication, as well as significant transformations of classical genres of Islamic communication, including sermons (khutba), religious hymns (anashid), and Islamic legal pronouncements (fatawa). Moreover, Skovgaard-Petersen shows how more sinister religious messages are currently being spread by Sunni jihadi militias that are mobilizing new media in their efforts to legitimize fighting and killing. Particularly, the Islamic State and Jabhat Fatah al-Sham ${ }^{2}$ have ventured into the online world on a massive scale and have revolutionized Islamic media messaging at many levels. However, as Skovgaard-Petersen argues, despite their "media-savviness", their lack of formal religious authority is potentially a point of weakness for these groups and may provide a way for the Muslim ulama to overcome a Sunni religious crisis.

Finally, Kanar Patruss examines the Islamic State's beheading videos of Western victims, which gained international attention and caused widespread outrage during the

\footnotetext{
${ }^{2}$ Formerly known as Jabhat al-Nusra.
} 
second half of 2014. After having noted how the images of the Islamic State's beheadings were mobilized in a Western political discourse classifying the Islamic State as nihilistic evil, Patruss offers a Nietzsche-inspired critique of the value judgment of evil in the Western discourse. More specifically, Patruss argues that a "rhetoric-of-goodversus-evil" overlooks the political character of the Islamic State's struggle for power and makes a "doctrine of destruction" appear as the only possible political measure against the Islamic State. Subsequently, Patruss seeks to nuance our understanding of the Islamic State through a "re-reading" of the beheading image. Drawing on Lene Hansen's concept of inter-iconicity (Hansen 2015), Patruss explores the inter-iconic relations between the image of the Islamic State's beheadings, on the one hand, and the decapitations of the French Revolution and the trope of the body politics, on the other. In doing so, Patruss presents a historically-sensitive understanding of the image of the Islamic State's beheadings, thereby establishing a platform for a more nuanced debate about the on-going war against the Islamic State and a broader critique of politically motivated violence.

Because of the international nature of the theme of this special issue, we have decided to allow our contributing authors to write in English, hoping that the articles may be of interest to audiences outside of Denmark.

\section{References}

Baumen, Z; Bigo D; Esteves, P; Guild, E and Jabri, V 2014, 'After Snowden: Rethinking the Impact of Surveillance', International Political Sociology, vol. 8, pp. 121144.

Der Derian, J 2013, 'From War 2.0 to Quantum War: The Superpositionality of Global Violence', Australian Journal of International Affairs, vol. 67, no. 5, pp. 570-585.

Hansen, L 2015, 'How images make world politics: International icons and the case of Abu Ghraib, Review of International Studies, vol. 41, no. 2, pp. 263-288.

Lynch, M 2016, The New Arab Wars: Uprising and anarchy in the Middle East, Public Affairs, New York.

Morozov, E 2011, The Net Delusion: The Dark Side of Internet Freedom, Public Affairs, New York.

Shirky, C 2011, 'The Political Power of Social Media: Technology, The Public Sphere, and The Political Change', Foreign Affairs, vol., 90, no. 1, pp. 17-21. 
Smith, R 2005, The Utility of Force. The Art of War in the Modern World, Penguin Books, London.

U.S. Department of State 2016, 'A New Center for Global Engagement', Fact Sheet, Office of the Spokesperson. Available at: http://www.state.gov/r/pa/prs/ps/2016/01/251066.htm

U.S. Department of State 2014, 'The Global Coalition to Counter ISIL'. Available at: http://www.state.gov/s/seci/index.htm

Wedeen, L 1999, Ambiguities of Domination: Politics, Rhetoric, and Symbols in Contemporary Syria, University of Chicago Press, Chicago. 